\title{
Article \\ Effects of Metal Fasteners of Ventilated Building Facade on the Thermal Performances of Building Envelopes
}

\author{
Abdulrahman Alghamdi *(D), Hamzah Alharthi, Abdulelah Alanazi and Mohammad Halawani \\ Mechanical Engineering Department, Umm Al-Qura University, Makkah 24382, Saudi Arabia; \\ haharthi@uqu.edu.sa (H.A.); noor711@msn.com (A.A.); mohammad.a.halawani@hotmail.com (M.H.) \\ * Correspondence: aasghamdi@uqu.edu.sa
}

Citation: Alghamdi, A.; Alharthi, H.; Alanazi, A.; Halawani, M. Effects of Metal Fasteners of Ventilated Building Facade on the Thermal Performances of Building Envelopes. Buildings 2021, 11, 267. https:// doi.org/10.3390/buildings11070267

Academic Editors: Zhenjun Ma and Fabrizio Ascione

Received: 31 May 2021

Accepted: 22 June 2021

Published: 24 June 2021

Publisher's Note: MDPI stays neutral with regard to jurisdictional claims in published maps and institutional affiliations.

Copyright: (c) 2021 by the authors. Licensee MDPI, Basel, Switzerland. This article is an open access article distributed under the terms and conditions of the Creative Commons Attribution (CC BY) license (https:/ / creativecommons.org/licenses/by/ $4.0 /)$.

\begin{abstract}
Thermal bridging in the building envelope is one of the main causes of energy losses, even in high-efficiency ventilated building façades. In this study, the effects of point-thermal bridges attributed to metal fasteners on the heat transferred through different types of bricks were predicted. All the structural details of the substrate wall were included as well. This was accomplished with a multi-scale, finite element modelling approach used to enhance the thermal insulation efficiency of the building envelope. The effects of the metal fastener length, diameter, density and location were examined to elucidate any opportunity to minimize the heat losses caused by thermal bridging. The results demonstrated that increases in the lengths of fasteners yielded higher energy losses compared with those generated when the diameter increased. Additionally, metal fasteners caused higher energy losses by up to $30 \%$ when fixed on mortar, compared with the energy losses incurred when they were fixed on bricks.
\end{abstract}

Keywords: thermal conductivity; metal fastener; building envelope; multi-scale; finite element modelling

\section{Introduction}

Globally, more than $40 \%$ of the total consumption of electrical energy is utilized by the residential sector. One-third of this proportion is used for space heating and cooling in buildings [1-4]. Unfortunately, the estimated heat losses through conventional building envelopes are approximately $60 \%$ [5]. Thus, interest in green building materials used for the building envelope has increased. A ventilated building facade system constitutes one of the promising solutions which are increasingly used worldwide in new and renovated buildings. Buildings with ventilated façades have increased thermal and structural efficiency and better resistance to moisture, noise and fire [6] than those with conventional façades. In these systems, the building envelope consists of a double-skin facade, wherein the external envelope has to be fixed to the substrate wall through anchoring systems. These anchoring systems should be strong enough to withstand the loads imposed by cladding panels (aluminum, wood, architectural concrete, ceramics, tiles, or natural stones) and to withstand wind and seismic loads $[7,8]$. Therefore, they are made of corrosion resistance metallic materials, such as stainless steel, galvanized steel, or aluminum. Compared with the insulation layer, the volume fraction of any anchoring system is extremely low. However, the thermal conductivity of these elements can be 2000 times higher than the insulation layer, which creates point-thermal bridges [6]. According to Theodosiou and his colleagues [9], the underestimation of heat flow caused by point-thermal bridging in aluminum cladding systems ranges from 5 to $20 \%$ depending on different factors.

The calculations of thermal bridging are complex and time consuming [10], owing to the complexity of the design and the large number of materials used in these systems. Therefore, many numerical studies $[5,10-15]$ have employed finite element (FE) methods to predict the effects of point-thermal bridges on the insulation efficiencies of buildings. In these studies, attention was paid on the cladding and anchoring elements, such as 
bracket design, and on profile, insulation and fastener materials. The role of the substrate wall has received less attention. A limited number of studies evaluated the effects of the material of the substrate wall on the thermal bridges. In Theodosiou et al. [6], FE analysis was carried out to predict the effect of the substrate wall material alongside with other wall parameters, such as the thickness of the wall and insulation. Theodoros and his colleagues [9] published a more detailed FE study. Empirical equations were developed by Šadauskiene et al. [16] to calculate the effect of the thermal conductivity of the substrate wall on thermal bridging. The economic impact of thermal bridging at different substrate walls was studied by Charvátová and Šubrt [17]. However, the substrate wall in all of these studies was modelled as a single homogeneous material with one varying thermal conductivity instead of modelling multiple phases with different thermal conductivities. This simplification may have led to the underestimation of the energy losses through thermal bridging. Modelling the wall based on the brick and concrete mortar details will result in FE models with a tremendous number of elements and will thus lead to prolonged computational times. Therefore, this study aims to investigate the effect of point-thermal bridges caused by metal fasteners on the heat transferred through different types of bricks using a multi-scale, FE modelling approach.

\section{Experimental Methods}

The experimental results of Al-Hadrami and Ahmad $[2,18]$ were used to validate the FE modelling results in this study. In the study, the authors used a guarded hot-plate system (Dynatech TCFG-R4-6) to determine the through-thickness thermal conductivity of different brick wall samples. The measurements were conducted in accordance with the American Society for Testing and Materials (ASTM) standard C177-85 [19]. The brick-wall sample had the following dimensions: length, $0.61 \mathrm{~m}$; height, $0.61 \mathrm{~m}$; thickness, $0.2 \mathrm{~m}$.

In the guarded hot-plate system, a heating plate was placed between a reference sample with known thermal conductivity and a brick-wall sample. Cooling plates were placed on the opposite surfaces of both samples, while the remaining surfaces were thermally insulated. Consequently, there was a constant heat flow towards the cooler surfaces of the samples. The total heat generated from the heating plate $Q$ was calculated as follows:

$$
Q=I \times V \times N
$$

where $I$ and $V$ are the current and voltage of the heating source, respectively. $N$ is a correction factor.

Heat transferred through the reference sample $Q_{R S}$ is determined using its thermal conductivity, which has a known value, by the following equation:

$$
Q_{R S}=\frac{A_{R S} \times k_{R S} \times\left(T_{h o t_{R S}}-T_{c o l d}\right)}{L_{R S}}
$$

where the subscript $R S$ denotes the reference sample and $A, k$ and $L$ are the surface area, thermal conductivity and thickness, respectively. $T_{\text {cold }}$ and $T_{\text {hot }}$ represent the temperatures of cold and hot sides of the sample, respectively.

Heat transferred through the brick wall samples $Q_{B S}$ is estimated by the following equation:

$$
Q_{B S}=Q-Q_{R S}
$$

where $Q$ is the total heat generated from the heating plate and $Q_{R S}$ is the heat transferred though the reference sample.

The thermal conductivity of the tested brick wall sample was then calculated as follows:

$$
k_{B S}=-\frac{Q_{B S}}{A_{B S}} \times \frac{L_{B S}}{T_{\text {hot }_{B S}}-T_{\text {cold }_{B S}}}
$$


where the subscript $B S$ denotes the brick-wall samples.

\section{FE Modelling}

\subsection{Geometrical Modelling}

Alghamdi and Alharthi $[4,20]$ adopted a multi-scale numerical homogenization approach to estimate the effective thermal conductivity of building walls constructed with different brick types and different insulation configurations. This study used the same approach, wherein the FE software package ABAQUS [21] was used to create the finite element models for different length scales. In the case of the first scale (brick scale), the thermal conductivities of different hollow brick types (red clay and concrete) were predicted. The resulted conductivities were respectively assigned to the brick phase in a brick-wall unit cell. The overall through thickness thermal conductivity of the brick wall was predicted from the second scale model (wall scale), which is the brick-wall unit cell. The results of the experimental work, previously described in Section 2, were then used to validate the technique. Metal fasteners were also added in the case of the second scale and the thermal conductivities of the walls with different dimensions, locations and configurations of metal fasteners were determined based on the unit cell of the brick wall.

\subsubsection{Brick Model}

The first scale models are three-dimensional finite element models of hollow concrete and red clay bricks, which are the most extensively used bricks in Saudi Arabia, and were constructed based on the measurements of their actual dimensions. The external dimensions of both bricks were $40 \times 20 \times 20 \mathrm{~cm}$. The red clay brick consisted of fired red clay $(36.2 \%)$ and cavities $(63.8 \%)$. There were twelve $3.9 \times 5.46 \mathrm{~cm}$ cavities which ran all the way along the longitudinal direction. The concrete brick only had dual $15 \times 12 \mathrm{~cm}$ cavities in the transverse direction. They occupied $43.4 \%$ of the total volume of the brick and the remaining $56.6 \%$ was concrete. Both brick models are shown in Figure 1. In both models, the cavities were given the properties of air.
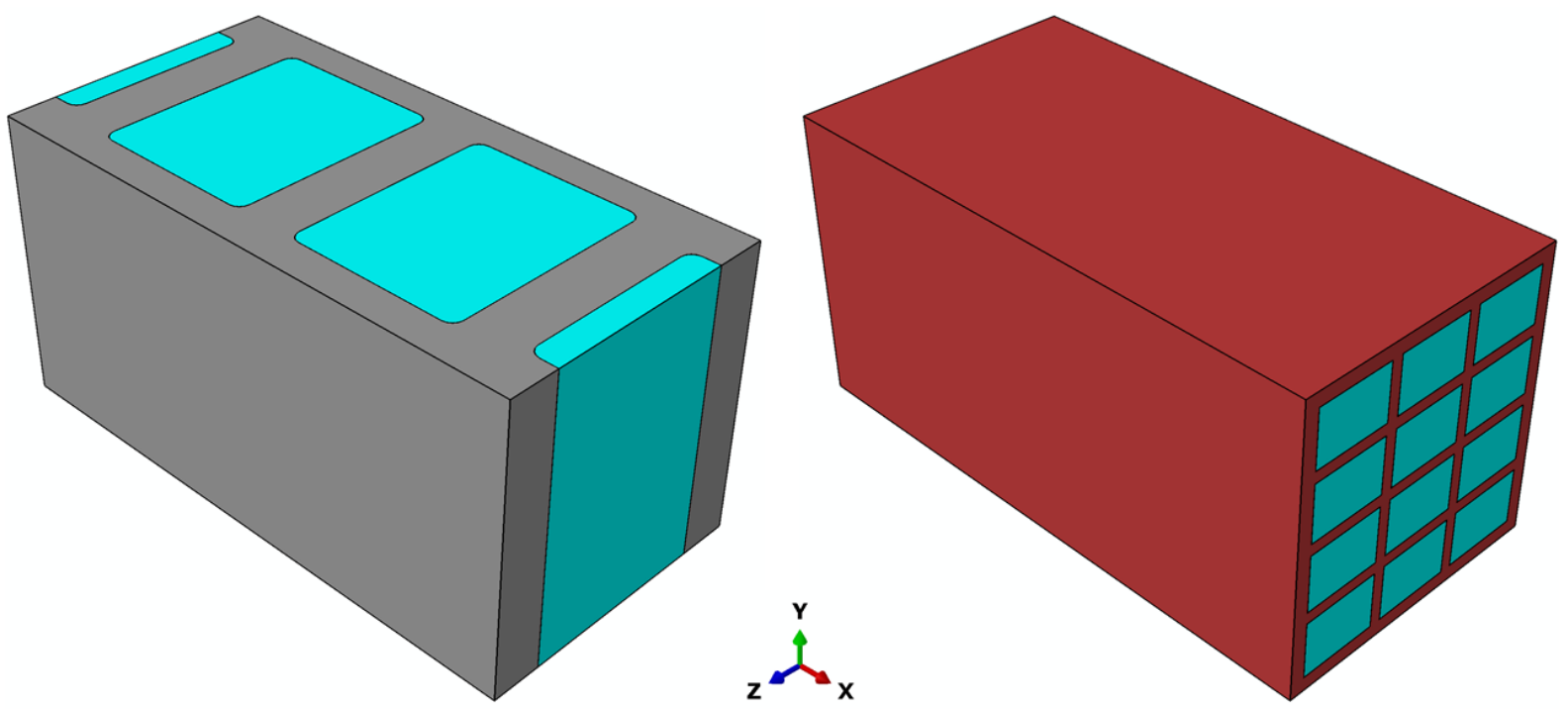

Figure 1. Concrete and red clay brick models.

\subsubsection{Brick-Wall Unit Cell}

Several studies [22-24] have previously simplified the brick wall by modelling a unit cell. This produced the structure of the wall by repeating the unit-cell motif (i.e., translating it) along the three spatial directions $\mathrm{X}, \mathrm{Y}$ and $\mathrm{Z}$. The adaptation of the unit-cell approach reduces the computational time. Figure 2 shows the brick-wall unit cell, which comprises bricks $93 \%$ and concrete mortar 7\% (thickness: $1 \mathrm{~cm}$ ). 

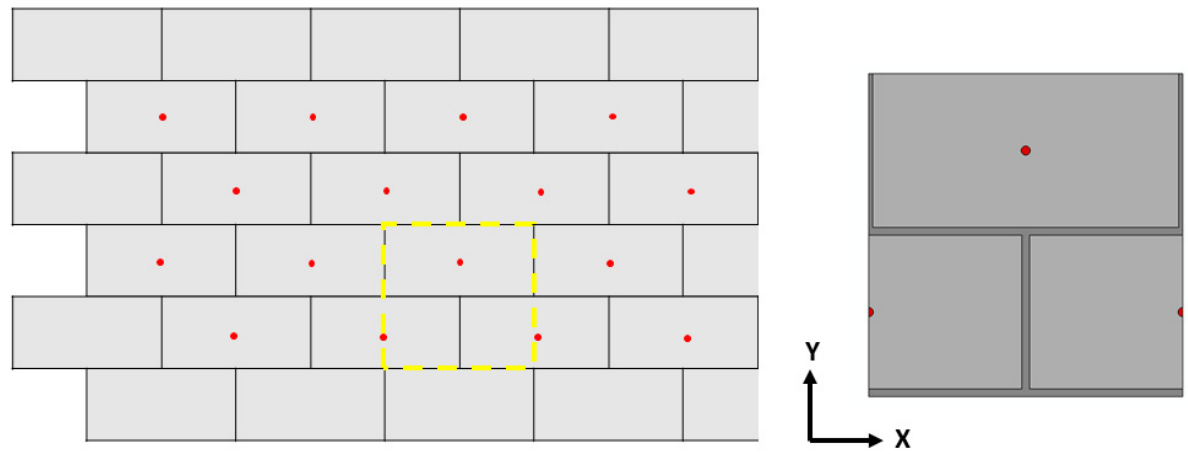

Figure 2. Unit cell of brick wall with metal fasteners.

Modelling the existing metal fasteners in the wall was simplified by cylindrical shapes embedded in the wall's unit cell. Their locations in the wall unit cell were selected carefully to match their predictable periodic features. The dimensions of the unit cell of the brick wall were: width, $0.41 \mathrm{~m}$; height, $0.42 \mathrm{~m}$; depth, $0.2 \mathrm{~m}$.

\subsection{Input Thermal Properties}

In reality, the properties of the envelope constituent materials are not constant due to their exposure to weather conditions [25]. However, these changes are small to be included in the analysis. Therefore, all material properties used in this study were assumed to be constant, as listed in Table 1.

Table 1. Thermal conductivities of the different phases in FE models.

\begin{tabular}{|c|c|c|}
\hline \multirow{2}{*}{ Material } & Thermal Conductivity & \multirow{2}{*}{ Source } \\
\hline & $(\mathrm{W} / \mathrm{m} \cdot \mathrm{K})$ & \\
\hline Fired red clay & 1.400 & [26] \\
\hline Concrete & 2.000 & [27] \\
\hline Standard mortar & 1.300 & [28] \\
\hline Air & 0.026 & [29] \\
\hline Galvanised steel & 61.980 & [30] \\
\hline
\end{tabular}

\subsection{Boundary Conditions}

The prediction of thermal conductivity with FE software can be achieved by implementing the same setup as the hot-guarded plate experiment. Simulating this experimental can be achieved by steady-state thermal analysis, whereby cold and hot temperatures ( $T_{\text {cold }}$ and $T_{\text {hot }}$ ) are applied on two opposite wall faces to simulate the cooling and heating plates, while the remaining surfaces are thermally insulated. $T_{\text {cold }}$ and $T_{\text {hot }}$ were set to $21^{\circ} \mathrm{C}$ and $30{ }^{\circ} \mathrm{C}$, respectively. The thermal conductivity $(k)$ can be determined using Equation (4).

To estimate the wasted energy caused by point-thermal bridging through metal fasteners a set of equations is used. The predicted thermal conductivity of the wall from the finite element analysis is used to calculate the thermal transmittance of the wall $U$, as follows:

$$
U=\frac{1}{R}=\frac{A K}{\Delta x}
$$

where $R, K, A$ and $\Delta x$ are the thermal resistance, thermal conductivity, surface area and thickness of the wall, respectively.

The amount of total heat following though the wall $Q$ is calculated based on the following relation:

$$
Q=U A\left(T_{\text {out }}-T_{\text {in }}\right)
$$


where $T_{\text {out }}$ and $T_{\text {in }}$ are the outdoor and indoor temperatures, which were set to $30{ }^{\circ} \mathrm{C}$ and $21{ }^{\circ} \mathrm{C}$, respectively. The outdoor temperature is the daily mean outdoor temperature of Makkah, Saudi Arabia, which has the highest cooling degree-days value in Saudi Arabia [31].

Equation (6) can be used to determine the heat transferred through the wall at different cases (with and without fasteners). These values were then utilized in the following relation to determine the wasted energy in each studied case:

$$
E_{w}=\frac{\left(Q_{F}-Q_{N}\right) \Delta t}{C O P}
$$

where $E_{w}$ is the wasted energy, $Q_{F}$ is the heat transferred through a wall containing metal fasteners, $Q_{N}$ is the heat transferred through a normal wall without any fasteners, COP is the coefficient of performance of the cooling system, which was set to 2.9 assuming window air conditioner, and $\Delta t$ is the annual equivalent of full-load cooling operation hours, which can be determined based on the following relation:

$$
\Delta t=O_{h} \frac{T_{\text {out }}-T_{\text {in }}}{T_{\text {design }}-T_{\text {in }}}
$$

where $O_{h}$ is the operation hours of the cooling system per year, which is $8760 \mathrm{~h} /$ year (i.e., $24 \mathrm{~h} /$ day in 365 day/year) and $T_{\text {design }}$ is the outdoor air design temperature, which was set to $37^{\circ} \mathrm{C}$.

\section{Results and Discussion}

\subsection{Technique Validation}

The accuracy of the proposed FE modelling procedure has been validated based on the results of our earlier studies $[4,20]$. The FE simulation results were compared with the experimental results conducted by Ahmad and Al-Hadrami [2] and Al-Hadrami and Ahmad [18]. Table 2 shows the predicted thermal conductivities for both brick types (red clay and concrete) in all three orthogonal directions (X, Y and Z). Based on these results, the wall thermal conductivities in through-thickness direction of both brick types were predicted and compared with the corresponding experimental results. Both experimental and finite element modelling results were in close agreement. Therefore, the implemented multi-scale finite element modelling technique is valid.

Table 2. Thermal conductivity results obtained from the finite element procedure and experimental work.

\begin{tabular}{cccccc}
\hline & & \multicolumn{2}{c}{$\begin{array}{c}\text { FE Modelling } \\
(\mathbf{W} / \mathbf{m} \cdot \mathbf{k})\end{array}$} & $\begin{array}{c}\text { Experimental } \\
\mathbf{( W / m} \cdot \mathbf{k})\end{array}$ \\
\cline { 2 - 6 } Brick Type & \multicolumn{3}{c}{ Brick Model } & Brick-Wall Unit Cell & Brick Wall Sample \\
\cline { 2 - 6 } & X-Direction & Y-Direction & Z-Direction & \multicolumn{2}{c}{ Through-Thickness } \\
\hline Red clay & 0.520 & 0.302 & 0.360 & 0.426 & 0.495 \\
\hline Concrete & 0.804 & 1.03 & 0.908 & 0.936 & 0.976 \\
\hline
\end{tabular}

\subsection{Effects of Metal Fastener Diameter}

Six brick-wall unit cell models, which contained metal fasteners with different diameters $(6,8,10,12,14$ and $16 \mathrm{~mm})$ and a fixed length $(100 \mathrm{~mm})$, were constructed. Steady-state boundary conditions were applied to all models in the $\mathrm{Z}$ direction to determine the throughthickness thermal conductivity of each model and compare it with the thermal conductivity of the unit cell of the brick wall which did not contain fasteners.

As is evident from the results shown in Table 3, increasing the diameter of the metal fasteners increases the thermal conductivity of the unit cell of the brick wall. However, it is higher in the red clay brick (diameter of $16 \mathrm{~mm}$ yielded an increase of 5.2\%) and 
the concrete brick (increase of 3.7\%). In contrast, the wasted energy caused by thermal bridging through the metal fasteners (Table 3 ) was predicted to be higher in the concrete brick wall compared with that wasted by red clay brick walls. As the diameter of the fastener increased, the difference in the wasted energy between red clay and the concrete brick wall also increased. At the diameters of 6 and $16 \mathrm{~mm}$, the differences were of 12 and $58 \%$, respectively.

Table 3. Thermal conductivities and energy wasted at different numbers of fasteners.

\begin{tabular}{|c|c|c|c|c|c|c|}
\hline \multirow{3}{*}{ Diameter (mm) } & \multicolumn{3}{|c|}{ Red Clay Bricks } & \multicolumn{3}{|c|}{ Concrete Bricks } \\
\hline & \multirow{2}{*}{$\begin{array}{c}\mathrm{K} \\
(\mathrm{W} / \mathrm{m} \cdot \mathbf{k})\end{array}$} & \multicolumn{2}{|c|}{ Energy Wasted } & \multirow{2}{*}{$\begin{array}{c}\mathrm{K} \\
(\mathrm{W} / \mathrm{m} \cdot \mathbf{k})\end{array}$} & \multicolumn{2}{|c|}{ Energy Wasted } \\
\hline & & $\left(\mathrm{kWh} / \mathrm{m}^{2}\right)$ & (kWh/Fastener) & & $\left(\mathrm{kWh} / \mathrm{m}^{2}\right)$ & (kWh/Fastener) \\
\hline 0 & 0.43 & - & - & 0.94 & - & - \\
\hline 6 & 0.43 & 0.52 & 0.05 & 0.94 & 0.58 & 0.05 \\
\hline 8 & 0.44 & 0.77 & 0.07 & 0.95 & 0.95 & 0.08 \\
\hline 10 & 0.44 & 1.01 & 0.09 & 0.95 & 1.35 & 0.12 \\
\hline 12 & 0.44 & 1.24 & 0.11 & 0.96 & 1.77 & 0.15 \\
\hline 14 & 0.45 & 1.46 & 0.13 & 0.97 & 2.21 & 0.19 \\
\hline 16 & 0.45 & 1.68 & 0.14 & 0.97 & 2.65 & 0.23 \\
\hline
\end{tabular}

\subsection{Effects of Metal Fastener Length}

The effects of the lengths of metal fasteners were investigated with the constructed nine brick-wall unit cells models with fixed diameters $(12 \mathrm{~mm})$ and different metal fastener lengths (varied from 20 to $180 \mathrm{~mm}$, at 20-unit increments). As listed in Table 4, the thermal conductivity of the wall increased with the metal fastener length. This increase was higher in the red clay brick case compared with the concrete brick case. However, the amount of energy wasted through the metal fastener in the concrete brick wall was found to be higher than that wasted through the red clay brick wall, as shown in Table 4.

Table 4. Thermal conductivities and energy wasted at different fastener lengths.

\begin{tabular}{|c|c|c|c|c|c|c|}
\hline \multirow{3}{*}{ Length (mm) } & \multicolumn{3}{|c|}{ Red Clay Bricks } & \multicolumn{3}{|c|}{ Concrete Bricks } \\
\hline & \multirow{2}{*}{$\underset{(W / m \cdot k)}{K}$} & \multicolumn{2}{|c|}{ Energy Wasted } & \multirow{2}{*}{$\underset{(W / m \cdot k)}{K}$} & \multicolumn{2}{|c|}{ Energy Wasted } \\
\hline & & $\left(\mathrm{kWh} / \mathrm{m}^{2}\right)$ & (kWh/Fastener) & & $\left(\mathrm{kWh} / \mathrm{m}^{2}\right)$ & (kWh/Fastener) \\
\hline 0 & 0.43 & - & - & 0.94 & - & - \\
\hline 20 & 0.43 & 0.08 & 0.01 & 0.94 & 0.09 & 0.01 \\
\hline 40 & 0.43 & 0.24 & 0.02 & 0.94 & 0.36 & 0.03 \\
\hline 60 & 0.43 & 0.49 & 0.04 & 0.95 & 0.76 & 0.07 \\
\hline 80 & 0.44 & 0.83 & 0.07 & 0.95 & 1.24 & 0.11 \\
\hline 100 & 0.44 & 1.24 & 0.11 & 0.96 & 1.77 & 0.15 \\
\hline 120 & 0.45 & 1.71 & 0.15 & 0.97 & 2.33 & 0.20 \\
\hline 140 & 0.46 & 2.23 & 0.19 & 0.97 & 2.92 & 0.25 \\
\hline 160 & 0.46 & 2.81 & 0.24 & 0.98 & 3.53 & 0.30 \\
\hline 180 & 0.47 & 3.46 & 0.30 & 0.99 & 4.19 & 0.36 \\
\hline
\end{tabular}

The effects of the metal fastener length and diameter have been combined in one figure. Figure 3 compares the energy wasted per fastener in red clay (red lines) and concrete (blue lines) brick wall at different fastener volume fractions. The volume fraction of the fastener is the ratio of the volume of the fastener to the total volume of the wall. Bold lines represent the transverse increase of the fastener volume owing to fastener diameter increases with the length fixed at $100 \mathrm{~mm}$. By contrast, the dashed lines denote the longitudinal increase in the volume owing to fastener length increases with the diameter fixed at $12 \mathrm{~mm}$. It can be observed that the longitudinal increase in the fastener volume wastes more energy than the transverse increase. For volume fractions $<3.3 \times 10^{-4}$, the opposite trends are 
observed. The reason for this finding is attributed to the fact that the length of the metal fastener was lower than $100 \mathrm{~mm}$, which is the fixed length of the fastener in case of the transverse increase of the fastener volume (bold lines). Therefore, at the same fastener volume fraction, more energy is wasted, when the fastener becomes longer. Based on this result, it is recommended to avoid using long fasteners and to replace them with short, thick fasteners.

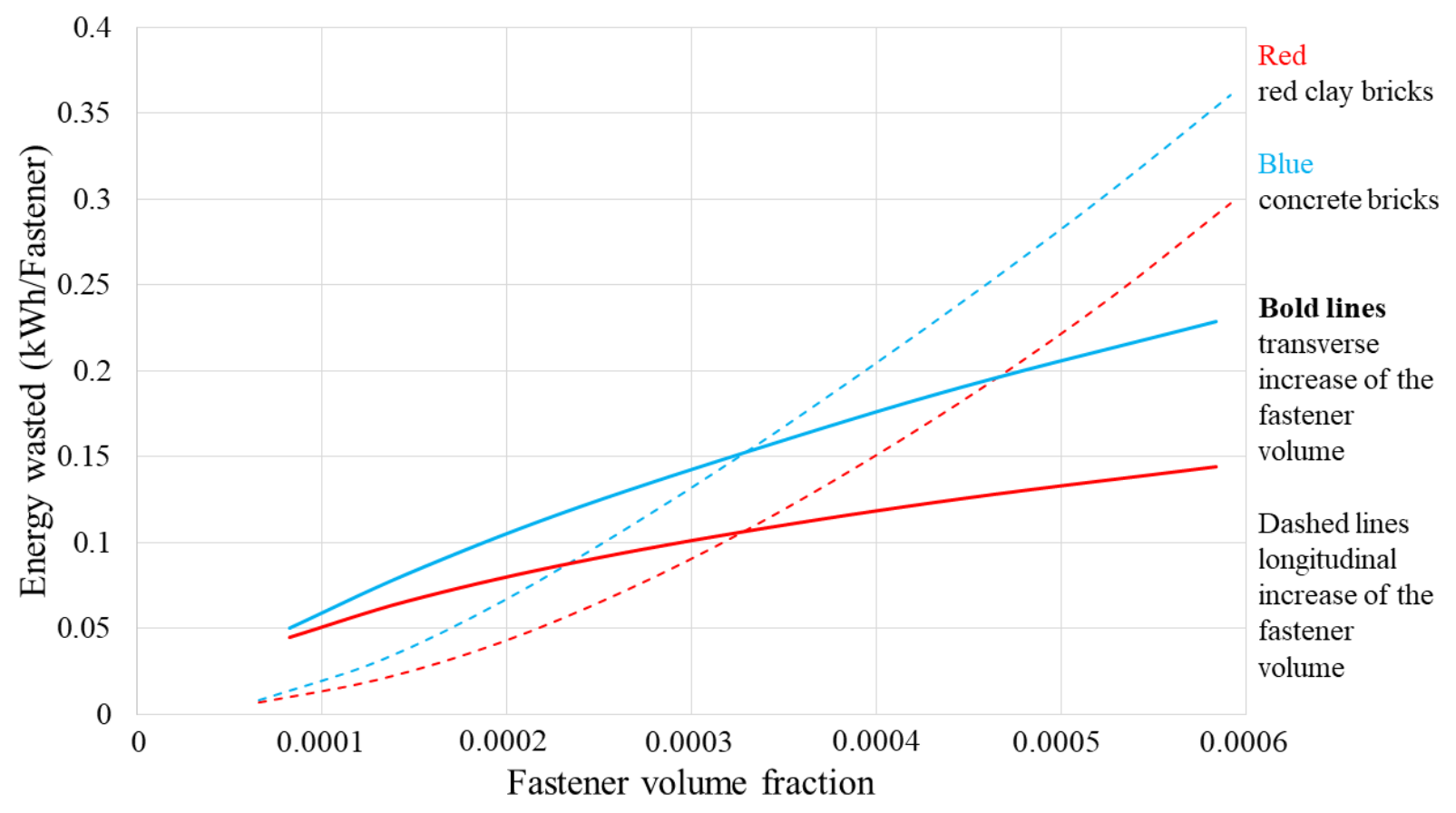

Figure 3. Energy wasted per fastener as a function of fastener volume fraction.

\subsection{Effects of Metal Fastener Density}

The effect of the density of metal fasteners (fasteners per unit area) was investigated with four brick-wall unit cells with fixed length $(100 \mathrm{~mm})$ and diameter $(12 \mathrm{~mm})$ but with different number of fasteners (1, 2, 3 and 4 fasteners). As listed in Table 5, the thermal conductivity of the wall increased as the metal fastener density increased. Similar to the effects of the parameters investigated previously, the increase in the thermal conductivity was higher in the case of the red clay brick compared with the concrete bricks. Moreover, this increase was found to be almost constant. Specifically, the single metal fastener in the first two models increased the wall thermal conductivity by 0.008 and $0.012 \mathrm{~W} / \mathrm{m} \cdot \mathrm{K}$ for red clay and concrete bricks, respectively. The increase was lower in unit cells in the brick wall which contained three and four fasteners. Specifically, the thermal conductivities of the red clay and concrete brick walls were increased by 0.006 and $0.01 \mathrm{~W} / \mathrm{m} \cdot \mathrm{K}$ per fastener, respectively.

Table 5. Thermal conductivities and energy wasted at different numbers of fasteners.

\begin{tabular}{|c|c|c|c|c|c|c|}
\hline \multirow{3}{*}{$\begin{array}{l}\text { Number of } \\
\text { Fasteners Per } \\
\text { Unit Cell }\end{array}$} & \multicolumn{3}{|c|}{ Red Clay Bricks } & \multicolumn{3}{|c|}{ Concrete Bricks } \\
\hline & \multirow{2}{*}{$\frac{K}{(W / m \cdot k)}$} & \multicolumn{2}{|c|}{ Energy Wasted } & \multirow{2}{*}{$\frac{K}{(W / m \cdot k)}$} & \multicolumn{2}{|c|}{ Energy Wasted } \\
\hline & & $\left(\mathrm{kWh} / \mathrm{m}^{2}\right)$ & (kWh/Fastener) & & $\left(\mathrm{kWh} / \mathrm{m}^{2}\right)$ & (kWh/Fastener) \\
\hline 0 & 0.43 & - & - & 0.94 & - & - \\
\hline 1 & 0.43 & 0.64 & 0.11 & 0.95 & 0.89 & 0.15 \\
\hline 2 & 0.44 & 1.24 & 0.11 & 0.96 & 1.77 & 0.15 \\
\hline 3 & 0.45 & 1.69 & 0.10 & 0.97 & 2.55 & 0.15 \\
\hline 4 & 0.45 & 2.12 & 0.09 & 0.98 & 3.31 & 0.14 \\
\hline
\end{tabular}


The wasted energy caused by thermal bridging through metal fasteners, as listed in Table 5, is predicted to be higher in the concrete brick wall compared with the red clay brick walls. The energy wasted per fastener was found to be decreased slightly when the fastener density in the concrete brick wall was increased. However, in the red clay brick wall this decrease was higher. Based on this result, it is recommended to use multiple short fasteners rather than one long fastener.

\subsection{Effects of Metal Fastener Location}

Concrete mortar has higher thermal conductivity than red clay and concrete bricks. Hence, fixing the metal fasteners in the mortar instead of bricks may cause more heat to transfer through the wall. To investigate the effect of the location of the metal fasteners on the thermal conductivity of the wall, two brick-wall unit cell models were constructed, which contained the same fasteners (lengths: $100 \mathrm{~mm}$; diameters: $12 \mathrm{~mm}$ ) but placed at different locations, as shown in Figure 4. All fasteners were fixed to the brick phase in the first model, whereas the second model had all the fasteners fixed to the mortar phase. Steady-state boundary conditions were applied to all the models in the $\mathrm{Z}$ direction to determine their thermal conductivity responses. As indicated by the results shown in Table 6, locating metal fasteners in the mortar increased the thermal conductivity of the brick-wall unit cell in both types of bricks, but this increase was higher in the red clay brick. Additionally, the wasted energy increased by $30 \%$ in the red clay brick wall case when the metal fasteners were located in the mortar. This increase was only $5 \%$ in the case of the concrete brick wall. Therefore, it is recommended to avoid fixing the fasteners of the anchoring system to the mortar phase of the substrate wall.

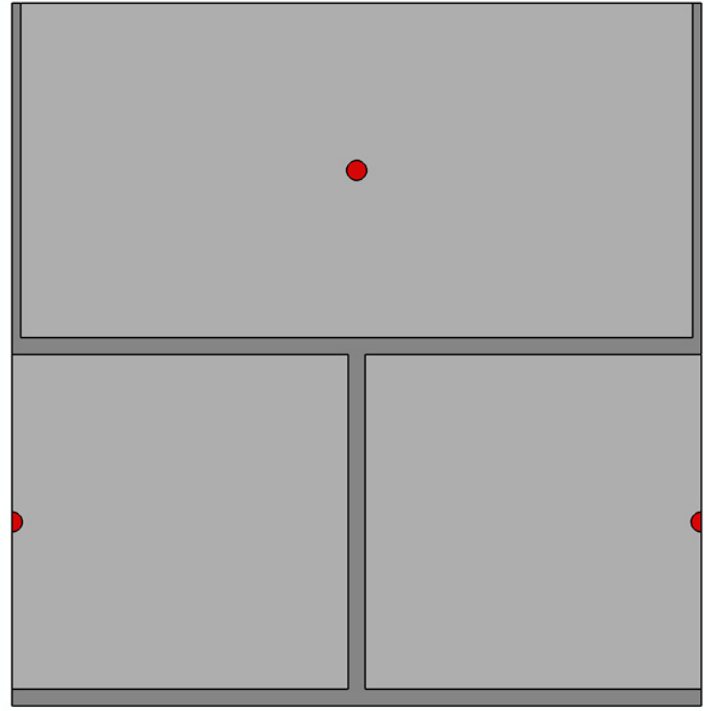

(a)

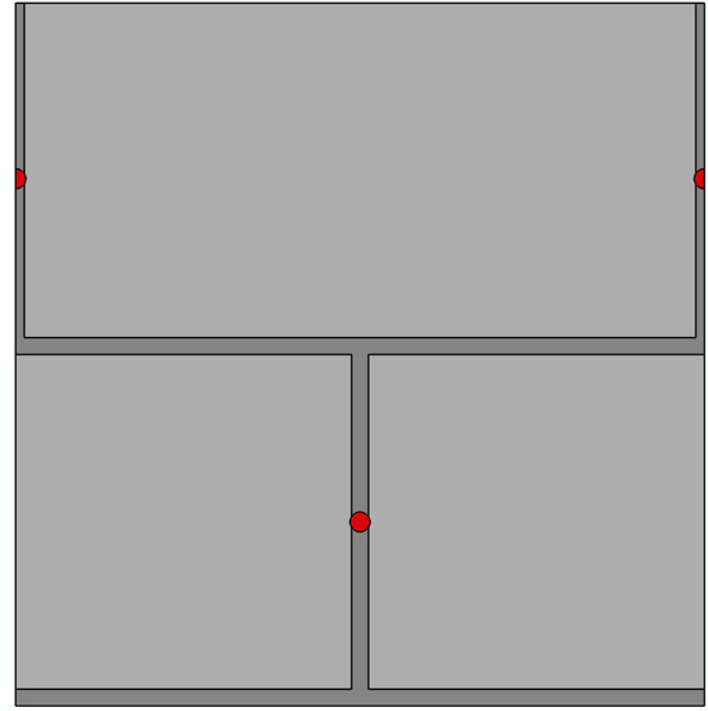

(b)

Figure 4. Fasteners at different (a) brick and (b) mortar locations.

Table 6. Thermal conductivities and energy wasted by brick walls with metal fasteners at different locations.

\begin{tabular}{|c|c|c|c|c|c|c|c|}
\hline \multirow{2}{*}{ Brick Type } & \multicolumn{2}{|c|}{$\begin{array}{l}\text { Thermal Conductivity } \\
(\mathrm{W} / \mathrm{m} \cdot \mathbf{k})\end{array}$} & \multicolumn{2}{|c|}{$\begin{array}{c}\text { Energy Wasted } \\
\text { (Fasteners at Bricks) }\end{array}$} & \multicolumn{2}{|c|}{$\begin{array}{c}\text { Energy Wasted } \\
\text { (Fasteners at Mortar) }\end{array}$} & \multirow{2}{*}{ Difference } \\
\hline & At Bricks & At Mortar & $\left(\mathrm{kWh} / \mathrm{m}^{2}\right)$ & $\begin{array}{c}(\mathbf{k W h} / \\
\text { Fastener) }\end{array}$ & $\left(\mathrm{kWh} / \mathrm{m}^{2}\right)$ & $\begin{array}{c}(\mathbf{k W h} / \\
\text { Fastener) }\end{array}$ & \\
\hline Red clay & 0.442 & 0.447 & 1.24 & 0.11 & 1.61 & 0.14 & $30 \%$ \\
\hline Concrete & 0.959 & 0.96 & 1.77 & 0.15 & 1.85 & 0.16 & $5 \%$ \\
\hline
\end{tabular}




\section{Conclusions}

Thermal analysis has been carried out on multi-scale FE models to predict the effects of metal fasteners on the thermal performance of the building envelope. The findings can be summarized as follows:

1. Wasted energy through metal fasteners in the concrete brick wall was higher than the red clay brick wall.

2. The higher the thermal conductivity of the substrate wall, the more prominent the effects of point-thermal bridging caused by metal fasteners.

3. The longitudinal increase in the fastener volume wasted more energy than the transverse increase. At the same volume fraction of fasteners, more energy was wasted when the length of the fastener increased.

4. The energy wasted per fastener decreased as the fastener density increased.

5. Fixing metal fasteners on the mortar caused more energy losses, by up to $30 \%$, compared with the case in which these were fixed on bricks.

Author Contributions: Conceptualization, A.A. (Abdulrahman Alghamdi) and H.A.; methodology, A.A. (Abdulrahman Alghamdi); software, A.A. (Abdulrahman Alghamdi) and H.A.; validation, A.A. (Abdulelah Alanazi), and M.H.; formal analysis, A.A. (Abdulrahman Alghamdi); investigation, H.A.; writing-original draft preparation, A.A. (Abdulrahman Alghamdi); writing-review and editing, H.A.; visualization, A.A. (Abdulelah Alanazi), and M.H.; supervision, A.A. (Abdulrahman Alghamdi) and H.A.; project administration, A.A. (Abdulrahman Alghamdi). All authors have read and agreed to the published version of the manuscript.

Funding: This research received no external funding.

Data Availability Statement: Not applicable.

Conflicts of Interest: The authors declare that there is no conflict of interest.

\section{References}

1. Balaras, C.A.; Gaglia, A.G.; Georgopoulou, E.; Mirasgedis, S.; Sarafidis, Y.; Lalas, D.P. European residential buildings and empirical assessment of the Hellenic building stock, energy consumption, emissions and potential energy savings. Build. Environ. 2007, 42, 1298-1314. [CrossRef]

2. Ahmad, A.; Al-Hadhrami, L.M. Thermal performance and economic assessment of masonry bricks. Therm. Sci. 2009, 13, 221-232. [CrossRef]

3. Bassiouny, R.; Ali, M.R.; NourEldeen, E.S. Modeling the thermal behavior of Egyptian perforated masonry red brick filled with material of low thermal conductivity. J. Build. Eng. 2016, 5, 158-164. [CrossRef]

4. Alghamdi, A.A.; Alharthi, H.A. Multiscale 3D finite-element modelling of the thermal conductivity of clay brick walls. Constr. Build. Mater. 2017, 157, 1-9. [CrossRef]

5. Arregi, B.; Garay-Martinez, R.; Astudillo, J.; García, M.; Ramos, J.C. Experimental and numerical thermal performance assessment of a multi-layer building envelope component made of biocomposite materials. Energy Build. 2020, 214, 109846. [CrossRef]

6. Theodosiou, T.; Tsikaloudaki, K.; Bikas, D. Analysis of the thermal bridging effect on ventilated facades. Procedia Environ. Sci. 2017, 38, 397-404. [CrossRef]

7. Finch, G.; Higgins, J. Cladding Attachment Solutions for Exterior Insulated Commercial Walls; RDH: Vancouver, BC, Canada, 2015.

8. Šadauskienè, J.; Ramanauskas, J.; Šeduikytè, L.; Daukšys, M.; Vasylius, A. A simplified methodology for evaluating the impact of point thermal bridges on the high-energy performance of a passive house. Sustainability 2015, 7, 16687-16702. [CrossRef]

9. Theodosiou, T.G.; Tsikaloudaki, A.G.; Kontoleon, K.J.; Bikas, D.K. Thermal bridging analysis on cladding systems for building facades. Energy Build. 2015, 15, 377-384. [CrossRef]

10. Cardoso, C.; Jalali, S. Thermal performance characterization of a modular system for façade. Key Eng. Mater. 2015, 634, 62-71. [CrossRef]

11. Ji, R.; Zhang, Z.; He, Y.; Liu, J.; Qu, S. Simulating the effects of anchors on the thermal performance of building insulation systems. Energy Build. 2017, 140, 501-507. [CrossRef]

12. Levinskytè, A.; Bliūdžius, R.; Burlingis, A.; Makaveckas, T. Dependencies of heat transmittance through the ventilated wall system on thermal conductivity of connectors crossing thermal insulation layer. MATEC Web Conf. EDP Sci. 2019, $282,02089$. [CrossRef]

13. Theodosiou, T.; Tsikaloudaki, K.; Tsoka, S.; Chastas, P. Thermal bridging problems on advanced cladding systems and smart building facades. J. Clean. Prod. 2019, 214, 62-69. [CrossRef]

14. Berardi, U.; Ákos, L. Thermal bridges of metal fasteners for aerogel-enhanced blankets. Energy Build. 2019, 185, 307-315. [CrossRef] 
15. Nowak, K.; Byrdy, A. Effect of mounting brackets on thermal performance of buildings with ventilated facades. J. Build. Phys. 2019, 43, 46-56. [CrossRef]

16. Šadauskienè, J.; Ramanauskas, J.; Vasylius, A. Impact of point thermal bridges on thermal properties of building envelopes. Therm. Sci. 2020, 42, 2181-2188. [CrossRef]

17. Charvátová, P.; Šubrt, R. Point thermal bridges at ventilated facade and impact on economics of building operation. In AIP Conference Proceedings, Proceedings of the Therophysics 2020, Smolenice, Slovak Republic, 7-9 September 2020; AIP Publishing LLC: Melville, NY, USA, 2020; Volume 2305, p. 020003. [CrossRef]

18. Al-Hadhrami, L.M.; Ahmad, A. Assessment of thermal performance of different types of masonry bricks used in Saudi Arabia. Appl. Therm. Eng. 2009, 29, 1123-1130. [CrossRef]

19. American Society for Testing and Materials (ASTM). C177-85 Standard Test Method for Steady-State Heat Flux Measurements and Thermal Transmission Properties by Means of the Guarded-Hot-Plate Apparatus; ASTM: West Conshohocken, PA, USA, 1985.

20. Alghamdi, A.A. Numerical investigation of thermal insulation options for non-insulated buildings in Saudi Arabia. Int. J. Ambient Energy 2019, 3, 1-7. [CrossRef]

21. Dassault Systemes Simulia Corporation. Abaqus 6.14; Dassault Systemes Simulia Corporation: Johnston, RI, USA, 2015.

22. Sacco, E. A nonlinear homogenization procedure for periodic masonry. Eur. J. Mech. A/Solids 2009, 28, 209-222. [CrossRef]

23. Uva, G.; Salerno, G. Towards a multiscale analysis of periodic masonry brickwork: A FEM algorithm with damage and friction. Int. J. Solids Struct. 2006, 43, 3739-3769. [CrossRef]

24. Addessi, D.; Sacco, E. A multi-scale enriched model for the analysis of masonry panels. Int. J. Solids Struct. 2012, 49, 865-880. [CrossRef]

25. Szodrai, F.; Lakatos, A. Effect of wetting time in the sorption and in the thermal conductivity of the most commonly used structural materials. Build. Serv. Eng. Res. Technol. 2017, 38, 475-489. [CrossRef]

26. ASHRAE. Handbook of Fundamentals; ASHRAE: Atlanta, GA, USA, 2009.

27. Nagy, B.; Paulik, E. Reinforcement-dependent thermal properties of reinforced concrete columns and slabs. Appl. Mech. Mater. 2017, 861, 279-286. [CrossRef]

28. Morales, M.P.; Juárez, M.C.; Muñoz, P.; Gómez, J.A. Study of the geometry of a voided clay brick using non-rectangular perforations to optimise its thermal properties. Energy Build. 2011, 43, 2494-2498. [CrossRef]

29. Lemmon, E.W.; Jacobsen, R.T. Viscosity and thermal conductivity equations for nitrogen, oxygen, argon, and air. Int. J. Thermophys. 2004, 25, 21-69. [CrossRef]

30. Singh, M.; Gulati, R.; Srinivasan, R.S.; Bhandari, M. Three-dimensional heat transfer analysis of metal fasteners in roofing assemblies. Buildings 2016, 6, 49. [CrossRef]

31. Al-Hadhrami, L. Comprehensive review of cooling and heating degree days characteristics over Kingdom of Saudi Arabia. Renew. Sustain. Energy Rev. 2013, 27, 305-314. [CrossRef] 